\title{
Endodontic Surgery
}

\author{
Marco Moreno Rojo and Jorge Paredes Vieyra* \\ School of Dentistry, Universidad Autónoma de Baja California, USA
}

Submission: April 02, 2018; Published: April 19, 2018

*Corresponding author: Jorge Paredes Vieyra, School of Dentistry, Universidad Autónoma de Baja California, Campus Tijuana, Tijuana, Baja California, USA, Tel: 01152(664)1230750; Email: jorgitoparedesvieyra@hotmail.com

\section{Opinion}

In recent times, we have witnessed technological advances in almost all areas of health sciences, endodontic surgery is no exception and it has also made significant progress with the help of surgical microscopy and complementary treatments with the use of biomaterials. Endodontic surgery follows the same principles applied in any surgical procedure that in essence are asepsis and antisepsis without overlooking the previous treatment of root canal; without it would be impossible to achieve the desired success; facing periapical infectious processes are truly a challenge due to the type of bacteria isolated in that biological complex. Surgical endodontic therapy is a predictable metbod of treatment because of its high success rate, and it is the treatment of choice for most patients presenting with evidence of pulpal and periradicular disease [1].

In 1884 Farrar described a "radical and heroic treatment of alveolar abscess by amputation of roots and teeth," and in 1897 Rhein' was advocating "amputation of roots as a radical cure in chronic alveolar abscess." G. V. Black,5 in 1886, was also advocating the total amputation of the individual roots of molars which were severely involved in periodontal disease with root canal filling of the remaining healthy roots [2].

The classic view that endodontic surgery is a last resort is based on past experience with accompanying unsuitable surgical instruments, inadequate vision, frequent postoperative complications, and failures that often resulted in extraction of the tooth. As a result, the surgical approach to endodontic therapy, or surgical endodontics, was taught with minimum enthusiasm at dental schools and was practiced by very few in private practices [3].

The concurrent development of better techniques has resulted I greater understanding of the apical anatomy, greater treatment success and a more favorable patient response. These developments marked the beginning of the endodontic microsurgery era that began in the 1990s.3 Today, endodontic surgery, in combination with root canal therapy, has become a remarkably successful method for the elimination of certain periapical pathoses [2].
The goal of endodontic treatment is to prevent or cure apical periodontitis (AP) caused by infection of the root canal systems of the affected teeth [1] or due to persistence of the primary infection or emergence of infection after treatment [2]. Periapical lesions are the most frequently diagnosed apical odontogenic pathologies in human teeth. The condition is generally described as apical periodontitis. The etiologic factor is the presence and colonization of microorganisms within the pulp canal system [1-3]. Bacterial stimulus cells cause intercellular mediators, humoral antibodies, and effector molecules to be released into the periapical tissues [4]. When bacteria colonize only in the apical ramifications of the root canal or outside the root canal or when pathosis is sustained by a periapical foreign body the surgical procedure effectively removes the infected site and enhances the chances of healing [3].

Apical ramifications, lateral canals, and isthmuses connecting main root canals have all been shown to harbor bacterial cells, which are also frequently organized in biofilm-like structures [46]. In their natural habitats, microorganisms almost invariably live as members of metabolically integrated communities commonly attached to surfaces to form biofilms [7]. The biofilm provides microorganisms with a series of advantages and skills including establishment of a broader habitat range for growth; increased metabolic diversity and efficiency; protection against competing microorganisms, host defenses, antimicrobial agents, and environmental stress; and enhanced pathogenicity [8].

In situ investigations [9-12] using optical and/or electron microscopy have allowed observations of bacteria colonizing the root canal system in primary or persistent/secondary infections as sessile biofilms covering the dentinal walls. Poor endodontic treatment allows canal reinfection, which may often lead to treatment failure [13]. Clinical signs and symptoms as well as radiographic evidence of periradicular lesions are usually associated with endodontic failure. When root canal therapy is performed according to accepted clinical principles and under aseptic conditions, the success rate is generally high. The host response is further characterized by bone resorption and an extraradicular infection resulting in radiolucency. An acute 
apical periodontitis or periapical abscess is associated with clinical signs of inflammation and pain.

Frequent indications for endodontic surgery have been suggested though contemporary practice proposes that endodontic surgery should be achieved only if conventional endodontic re-treatment will not remove potential areas of canal infection such as in an un-instrumented portion of a canal or will have the potential to irreversibly injury the tooth for example root fracture following to post removal, or if previous re-treatment has not resulted in healing [14].

Apical periodontitis is one of the most common pathological conditions within alveolar bone. Apical periodontitis consists of an inflammation and destruction of the tissues around the root of the teeth caused by etiological agents of endodontic origin $[14,15]$.

It is usually a sequel of an endodontic infection that turns the dental pulp into a necrotic tissue infected by autogenous oral bacteria. This infection usually occurs through dental hard tissue damage resulting from caries, clinical procedures, or trauma and it provokes an inflammatory process that stimulates the proliferation of the cell rests of Malassez in the periodontal ligament [15]. The development of apical periodontitis can occur due to different mechanisms, such as accumulation of osmotic fluid in the lumen, proliferation of epithelial cell rests of Malassez, or molecular mechanisms [16]. As a result, clinicians often make clinical and radiographic diagnoses, and the removed periapical tissues are seldom submitted for histopathological analysis [17]. Clinical and radiological evaluations alone cannot properly identify the type of lesion in the apical area $[18,19]$.

Many factors are involved in the healing process of a periapical defect following endodontic surgery [20]. Amongst these, the 2 layers of the periosteum are very important because they may act both as a source of osteo-competent cells and as a barrier against the infiltration of epithelial cells into the healing site. However, in large defects the periosteum is often damaged by the infective process [21].

\section{References}

1. Gutmann J (1985) Posterior endodontic surgery: anatomical considerations and clinical techniques. Int Endod J 18(1): 8-34.

2. Luebke R (1964) Indications and contraindications for endodontic surgery. American association of endodontics. 18(1): 97-113.

3. Kim S (2006) Modern endodontic surgery concepts and practice: A review. J Endod 32(7): 601-623.

4. Nair PN, Henry S, Cano Vera J (2005) Microbial status of apical root canal system of human mandibular first molars with primary apical periodontitis after "one-visit" endodontic treatment. Oral Surg Oral Med Oral Pathol Oral Radiol Endod 99(2): 231-252.

5. Ricucci D, Siqueira JF Jr, Bate AL (2009) Histologic investigation of root canal-treated teeth with apical periodontitis: a retrospective study from twenty-four patients. J Endod 35(4): 493-502.

6. Ricucci D, Siqueira JF Jr (2010) Fate of the tissue in lateral canals and apical ramifications in response to pathologic conditions and treatment procedures. J Endod 36(1): 1-15.

7. Costerton JW (2007) The biofilm primer. Berlin, Heidelberg: SpringerVerlag.

8. Marsh PD (2005) Dental plaque: biological significance of a biofilm and community lifestyle. J Clin Periodontol 32(suppl 6): 7-15.

9. Ramachandran Nair PN (1987) Light and electron microscopic studies of root canal flora and periapical lesions. J Endod 13: 29-39.

10. Siqueira JF Jr, Roças IN, Lopes HP (2002) Patterns of microbial colonization in primary root canal infections. Oral Surg Oral Med Oral Pathol Oral Radiol Endod 93(2): 174-178.

11. Molven O, Olsen I, Kerekes K (1991) Scanning electron microscopy of bacteria in the apical part of root canals in permanent teeth with periapical lesions. Endod Dent Traumatol 7(5): 226-229.

12. Carr GB, Schwartz RS, Schaudinn C (2009) Ultrastructural examination of failed molar retreatment with secondary apical periodontitis: an examination of endodontic biofilms in an endodontic retreatment failure. J Endod 35(9): 1303-1309.

13. Peters LB, Wesselink PR, Moorer WR (1995) The fate and the role of bacteria left in root dentinal tubules. Int Endod J 28(2): 95-99.

14. Love RM, Firth N (2009) Histopathological profile of surgically removed persistent periapical radiolucent lesions of endodontic origin. Int Endod J 42(3): 198-202.

15. Nair PNR (2006) On the causes of persistent apical periodontitis: a review. Int Endod J 39(4): 249-281.

16. Nair PNR, Sjögren U, Sundqvist G (1998) Cholesterol crystals as an etiological factor in non-resolving chronic inflammation: an experimental study in guinea pigs. Eu J Oral Scien 106(2 pt 1): 644650 .

17.Wang Q, Cheung GSP, Ng RPY (2004) Survival of surgical endodontic treatment performed in a dental teaching hospital: A cohort study. Int Endod J 37(11): 764-775.

18. Cotti E, Campisi G, Ambu R, Dettori C (2003) Ultrasound real time imaging in the differential diagnosis of periapical lesions. Int Endod J 36(8): 556-563.

19. Ricucci D, Mannocci F, Ford TR (2006) A study of periapical lesions correlating the presence of a radiopaque lamina with histological findings. Oral Surg Oral Med Oral Pathol Oral Radiol Endod 101(3): 389-394.

20. Sjögren U, Hagglund B, Sundqvist G (1990) Factors affecting the longterm results of endodontic treatment. J Endod 16(10): 498-504.

21. Pecora G, De Leonardis D, Ibrahim N (2001) The use of calcium sulphate in the surgical treatment of "through and through". periradicular lesion. Int Endod J 34: 189-197. 
This work is licensed under Creative Commons Attribution 4.0 License

DOI: 10.19080/GJO.2018.14.555898
Your next submission with Juniper Publishers will reach you the below assets

- Quality Editorial service

- Swift Peer Review

- Reprints availability

- E-prints Service

- Manuscript Podcast for convenient understanding

- Global attainment for your research

- Manuscript accessibility in different formats

( Pdf, E-pub, Full Text, Audio)

- Unceasing customer service

Track the below URL for one-step submission https://juniperpublishers.com/online-submission.php 